原著特性 X線による組織内遷移金属の分析（I ）

——筋・皮膚内 $\mathrm{Au}$ 銊刺入による各種金属イオンの動静——

二本柳 賢司 ${ }^{*}$ 小野 了一 加藤 隆平

要旨：遷移金属鍼刺入の影響による生体内金属イオンの存在様態を決定するた めに，特性 X線スペクトルの分析を試みた。

その結果, 刺入遷移金属銊のイオン化の定性とイオンの拡散分布方程式，イ オン移動係数に等しい拡散係数そしてイオンの拡散速度を導びいている。

他方，刺入金属銊のイオン化量は刺激時間の増大に伴い増加して，このこと は特に筋肉において顕著である。また, Kイオンの内在量は刺激時間の増大に伴 い減少し，さらに刺入銊の通電により組織内各種金属イオンの相対的濃度比が 変動することを確認している。

これらの結果に対して，金属蛋白の観点より若干の考察を加えている。

\section{1. 緒言}

生体での微量元素の多くが金属酵素の活性中心 に存在し，酵素の活性発現と構造維持に不可欠の 存在であることがわかってきている。金属イオン の大部分は遷移金属であり，それ自身が酸化還元 能や加水分解能などの酵素類似作用を持ち，更に 蛋白と結合して最高度の触媒作用を発揮すること はよく知られている ${ }^{1 \sim 4)}$ 。

鍼刺入による諸作用を鍼成分の生体内でのイオ ン化に起因する諸効果として把之，生体内金属イ オンの存在様式を物理化学，生化学の観点より研 究することが重要であるということを我々は既に 示してきた ${ }^{5 \sim 6)}$ 。

今回の実験は以上の観点に立脚して，銊刺入に よるイオン化の状況，イオン分布状態を定性的に かつ半定量的に決定することを目的とした。

\section{2. 実験方法}

1）元素分析原理

※ Kenji Nihonyanagi 名古屋市立大学医学部第一生理学 教室 立命館大学理工学院研究所

共同研究者: Ryoichi Ono, Ryuhei Kato 立命館大学理 工学部数学物理学科原子核物理学教室

Key Word : metals, cations, trace elements, diffusion, characteristicX-rays.
高速電子が物質に当った時, 電子は物質を構成 する原子の電子または原子核と衝突または相互作 用をする。内殼の電子は原子核と強く引っぱり 合っているので, これを引き離すにはエネルギー を必要とする。例えばK殼の結合エネルギーを $\mathrm{W}_{\mathrm{K}}$ とし，たたき出された電子の運動エネルギーを $\mathrm{E}_{2}$ とすれば, 初めの電子の失うエネルギーは, $\Delta \mathrm{E}_{3}=$ $\mathrm{E}_{2}+\mathrm{W}_{\mathrm{K}}$ となり, 初めの電子のエネルギーは, $\mathrm{E}-$ $\Delta \mathrm{E}_{3}$ となる。この時, 原子はイオンとなるが, $\mathrm{K}$ 殼 に一つの空席ができるので，より外側の電子が 引っぱられて落ちてくる。この時，エネルギーが 余り，それがX線となって放出される。元素によ り核外電子のエネルギーレベルは決っているの で，その間に転移があった時に余るエネルギーは 元素の種類によって一定であって，生ずるエネル ギーはX線となる。これが特性 X 線 (characteristic X-rays) である。外殼電子のエネルギーレべ ルの差により，L殼から落ちてくるのがK $\alpha$ 線， $\mathrm{M}$ 殼から落ちてくるのが $\mathrm{K} \beta$ 線等となり， $\mathrm{L}, \mathrm{M}$ 殼の 微細構造により，さらにそれが何本かに分かれる のである。また同様に, L殼や $\mathrm{M}$ 殼に空席ができて も同様にL線, M線などが出るが, エネルギーが小 さいので途中で吸収されて余りよく検出できな い。

特性 $\mathrm{X}$ 線の発生のためには, 電子線のエネル ギーが各々の殼電子の結合エネルギーより大きい 


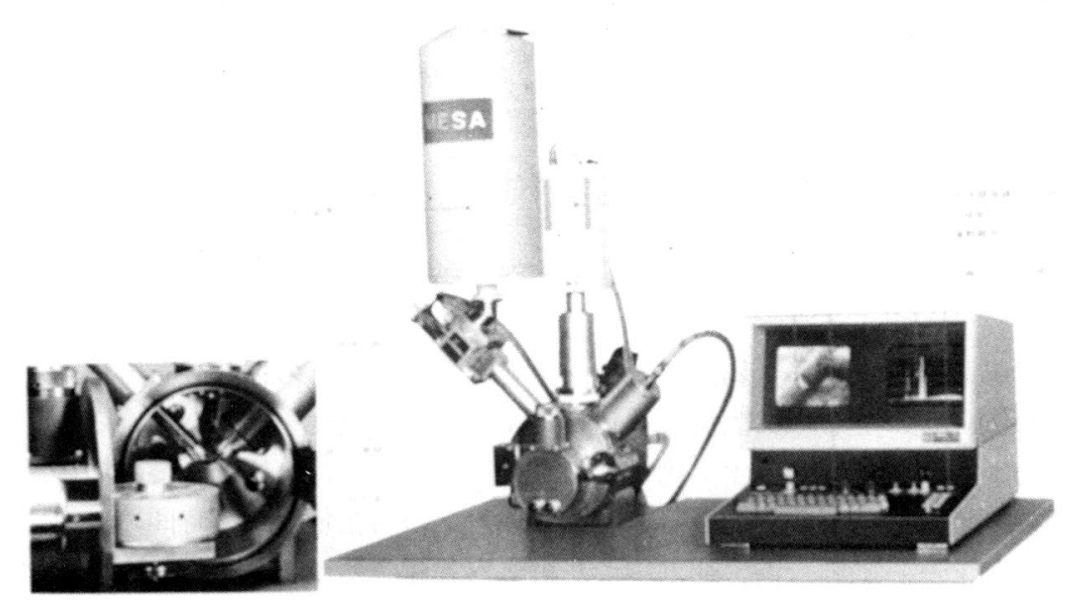

Photo. I analyzer of the characteristic X-rays

ことが必要であるから, 各々の特性X線を出すに は必要な最低管電圧がある。これが励起電圧であ る。励起電圧は原子番号の大きい程, M線, L線, $\mathrm{K}$ 線の順に大きくなる。

\section{2 ）分析装置}

照射X線をコリメーターによってコリメート可 能にする分析装置 (堀場製作所製 X 線分析装置 MESA-1130) を使用した (photo. I )。

3 ) 実験材料および寒験方法

実験動物は健康なニワトリを使った。実験部位 は, 手羽部の皮膚ならびにはその皮膚直下の筋肉 を, 縦 $2 \mathrm{~cm}$, 横 $1 \mathrm{~cm}$, 厚さは皮膚の厚さ $1.5 \mathrm{~mm}$ に等しい厚さの直方体状に切除し, 恒温槽 $\left(35^{\circ} \mathrm{C}\right)$ 内生理食塩水中に保存しつつ, 次の五群に分けて 実験した。

\section{第一群はコントロールの皮虐と筋肉。}

第二群は 10 分間刺入の皮虚も筋肉。

第三群は20 分間刺入の皮膚と筋肉。

第四群は 30 分間刺入の皮膚と筋肉。

第五群は 1200 分間刺入の皮虜と筋肉。

であり，第一群を除く第二群より第五群までに対 して, 直径 $0.3 \mathrm{~mm}$ の純金 $(\mathrm{Au})$ の鍼を刺入し, 同時に約 $10 \mu \mathrm{A}, 9 \mathrm{~V}, 25 \mathrm{HZ}$ 低周波通電を行っ た。規定通電後, 試料から鍼を抜き, そのままの 状態で試料を分析装置の試料室に設置し, 試料室 を真空状態にして分析した。試料室内の試料を光 学顕微鏡式ビデオカメラで分析領域を観察しなが ら特性X線分析を同時に行った。分析が終り次第,
装置内臓のコンピューターによって即座に測定結 果をディスプレイ表示した。

照射 $\mathrm{X}$ 線のエネルギーは軽元素用のためには

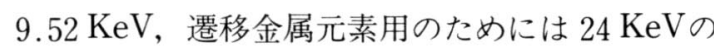
二つを使った。ターゲットはタングステンである。 $\mathrm{X}$ 線検出には堀場製作所製リチウム・ドリフト・ シリコン; $\mathrm{Si}(\mathrm{Li})$ 半導体Beウインド一検出器を 用いている。

$\mathrm{X}$ 線検出器に対するビーム入射角度は 90 度で ある。X 線検出の分解能は, 半值幅で $6 \mathrm{KeV}$ と き $140 \mathrm{eVであった。}$

\section{3. 実験結果}

1）刺入金属鍼のイオン化と拡散分布

Fig.1，2はそれぞれ第三群，第四群の試料につ き, 皮膚および筋肉を別々に $9.52 \mathrm{KeV}$ の 線に より励起した時の特性X線を捕えたものであり, 一つのヒストグラムの幅は試料上で $0.3 \mathrm{~mm}$ 直 径を持つ円柱内の金属鍼成分 $(\mathrm{Au})$ のイオン存在 量を示している。なお,この一つのヒストグラム 幅は刺入金属鍼の直径 $(0.3 \mathrm{~mm})$ に一致させてあ る。

拡散イオンの分布の仕方は鍼刺入部が最も多量 のイオン分布となり, 鍼刺入部から離れれば離れ る程, イオンの存在量は減少する。Fig. 3 は Fig. 1，2を両対数グラフで表示しえたものであ る。横軸は鍼刺入部からの距離 $(\mathrm{mm}$ 単位 $)$ をとり, 縦軸はFig. 1，2 から読み取れたヒストグラムの 
相対的な数值を読み取ったものである。このFig. 3 より，鍼のイオン化によるイオンの分布方程式 として, 次の方程式が導びかれた。

拡散分布量を $\mathrm{I}$, 拡散係数を $\mathrm{D}$, 銊刺入部からの 距離を $\chi$, 鍼刺入部での金属量を $\mathrm{I}_{0}$ とすれば,

$$
\log \mathrm{I}=-\mathrm{D} \log x+\log \mathrm{I}_{0}
$$

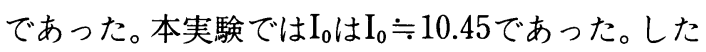
がって, $\mathrm{I} \fallingdotseq 10.45(-x)^{-\mathrm{D}}$ となった。

また, 20 分後, 30 分後の拡散係数をそれぞれ $\mathrm{D}_{20}, \mathrm{D}_{30}$ とし, さらに対極 $(-)$ 向っての拡散係 数, 対極 (一) から離れる拡散係数をそれぞれD $\mathrm{D}^{\mathrm{O}}$ によって表わすと, $\mathrm{D}_{20}^{\mathrm{I}} \fallingdotseq 0.41, \mathrm{D}^{\mathrm{I}}{ }_{30} \fallingdotseq 0.43$, $\mathrm{D}^{0}{ }_{20} \fallingdotseq 0.43, \mathrm{D}^{\mathrm{o}}{ }_{30} \fallingdotseq 0.59$ であった。これらすべての 拡散係数の平均, すなわち平均拡散係数 $\mathrm{D} は \mathrm{D} \fallingdotseq 0$. 46 であった。また，拡散平均速度 $\bar{v}$ $\mathrm{min}) \leqq \bar{v} \leqq 0.9(\mathrm{~mm} / \mathrm{min})$ であった。

2.アルカリ金属および遷移金属の定性的分析 結果

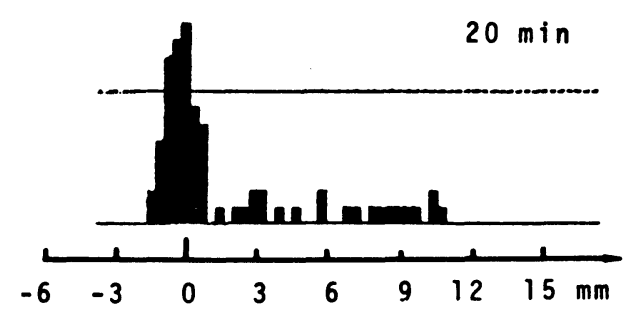

Fig. I Diffusion of $\mathrm{Au}$

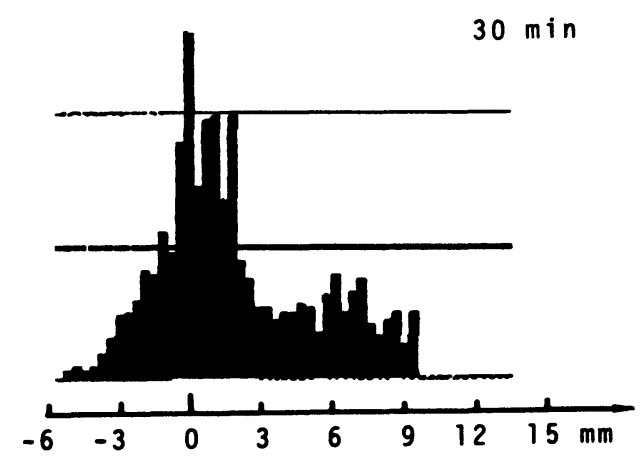

Fig. 2 Diffusion of $\mathrm{Au}$
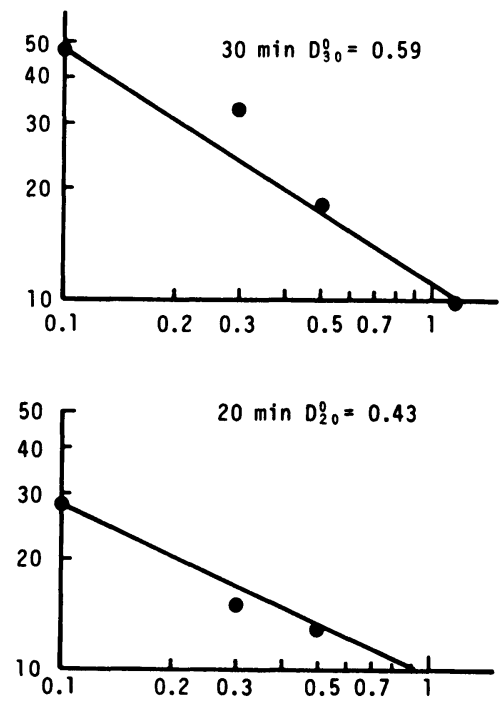

Fig. 3 Diffusion \& Distribution of Au

Fig. 4 は銊刺入前の X 線スペクトルであり， Fig. 5 は筋肉における一定時間後の各種金属の分 布変化を示している。Fig. 6 は皮膚における一定 時間後の各種金属の分布変化を示している。それ ら金属の量的存在比はTable 1 の通りであった。
このTableは筋肉および皮膚に含まれている鉄 (Fe) の量がほぼ一定であることに着目して, 鉄 の量を 100 とした時の，各種金属の量の相対分率 を計算したものである。 


\section{4. 考察}

〔刺入金属銊のイオン化量とイオンの拡散分布 方程式について〕

Hodgkin, A.F.Huxley (1952)の透過係数（permeability coefficient)Pは, ${ }^{9}$

$$
\mathrm{P}=\frac{\mu \beta \mathrm{RT}}{\mathrm{AF}}
$$

ただし， $\mu$ は $\mathrm{cm}^{2} /$ volt・secで表わした粒子の移動 度，及は分配係数， $\mathrm{A}$ は膜の厚さ，Fはファラデー 定数，Rは気体定数である。しかし，このPは多数 の連続した生体膜の集合である組織の透過性に対 しては，距離（組織の大きさを表わすものとして の）に関する定数が決っていない。この定数を決

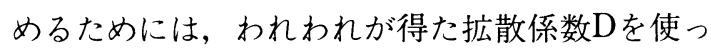
て次のようにすればよい。

\section{まず，イオンのフラックス（流動束）Jは}

$$
\mathrm{J}=\omega \times \mathrm{C} \times \mathrm{f}_{\mathrm{N}}
$$

ただし, いは単位濃度, Cは移動するイオン濃 度， $\mathrm{f}_{\mathrm{N}}$ はN個のイオン群に働く力とすることがで きる ${ }^{10)}$ 。また,

$$
\mathrm{f}_{\mathrm{N}}=-\mathrm{RT} \frac{\mathrm{d} \ln \mathrm{C}}{\mathrm{d} x}-\mathrm{ZF} \frac{\mathrm{d} \phi}{\mathrm{d} x}
$$
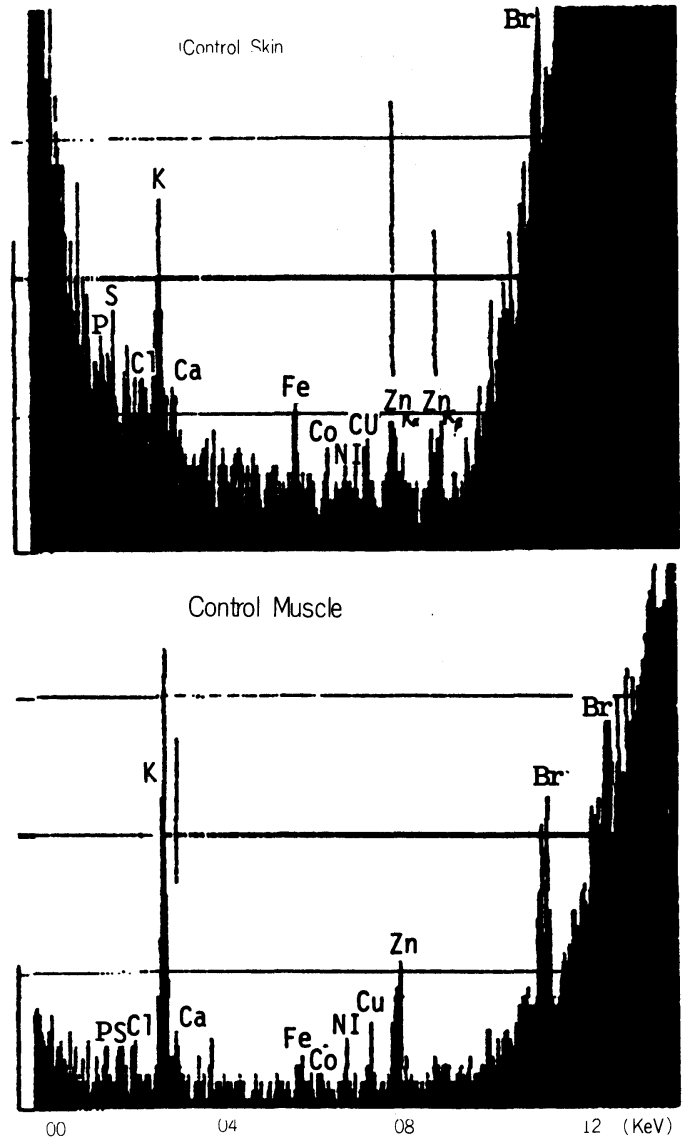

\begin{tabular}{|c|c|c|c|c|c|c|c|c|c|c|c|}
\hline & \multirow{3}{*}{$\frac{\text { Group }}{4 \text { 4th.period }}$} & \multicolumn{2}{|c|}{$\begin{array}{l}\text { Alkali } \\
\qquad \text { Metals }\end{array}$} & \multicolumn{7}{|c|}{ Transition Metals } & \multirow{3}{*}{$\begin{array}{l}\mathrm{Ib} \\
\mathrm{Au}\end{array}$} \\
\hline & & \multirow{2}{*}{\begin{tabular}{c|}
$\mathrm{I} a$ \\
$\mathrm{k}$
\end{tabular}} & \multirow{2}{*}{\begin{tabular}{l|}
$\mathrm{II} \mathrm{a}$ \\
$\mathrm{Ca}$
\end{tabular}} & \multirow{2}{*}{$\frac{\mathrm{VIa}}{\mathrm{Cr}}$} & \multirow{2}{*}{$\frac{\mathrm{VII}}{\mathrm{Mn}}$} & \multicolumn{3}{|c|}{ VIII } & \multirow{2}{*}{$\frac{\mathrm{II} \mathrm{b}}{\mathrm{Cu}}$} & \multirow{2}{*}{$\frac{\mathrm{II} \mathrm{b}}{\mathrm{zn}}$} & \\
\hline & & & & & & $\mathrm{Fe}$ & Co & $\mathrm{Ni}$ & & & \\
\hline \multirow{2}{*}{ Control } & Skin & 240 & 110 & 65 & 0 & 200 & 70 & 55 & 75 & 85 & 0 \\
\hline & Muscle & 1000 & 143 & 0 & 0 & 100 & 57 & 129 & 171 & 286 & 0 \\
\hline \multirow{2}{*}{$\begin{array}{l}\text { after } 10 \mathrm{~min} \\
\text { acupuncture }\end{array}$} & Skin & 62 & 52 & 48 & 0 & 100 & 34 & 62 & 31 & 83 & 103 \\
\hline & Muscle & 245 & 145 & 0 & 55 & 100 & 45 & 82 & 145 & 265 & 118 \\
\hline \multirow{2}{*}{$\begin{array}{l}\text { after } 30 \mathrm{~min} \\
\text { acupuncture }\end{array}$} & Skin & 88 & 63 & 50 & 0 & 100 & 63 & 63 & 175 & 175 & 400 \\
\hline & Muscle & 123 & 123 & 76 & 82 & 100 & 47 & 99 & 182 & 327 & 141 \\
\hline \multirow{3}{*}{$\begin{array}{l}\text { after } 1200 \mathrm{~min} \\
\text { acupuncture }\end{array}$} & Skin & 1117 & 75 & 67 & 0 & 100 & 42 & 42 & 75 & 100 & 199 \\
\hline & Muscle & 69 & 69 & 62 & 69 & 100 & 38 & 38 & 92 & 215 & 1307 \\
\hline & & \multicolumn{9}{|c|}{ ratio of existence $\quad(\mathrm{Fe}=100)$} & \\
\hline
\end{tabular}

Fig. 4 Distribution of Cations

Table 1 . 

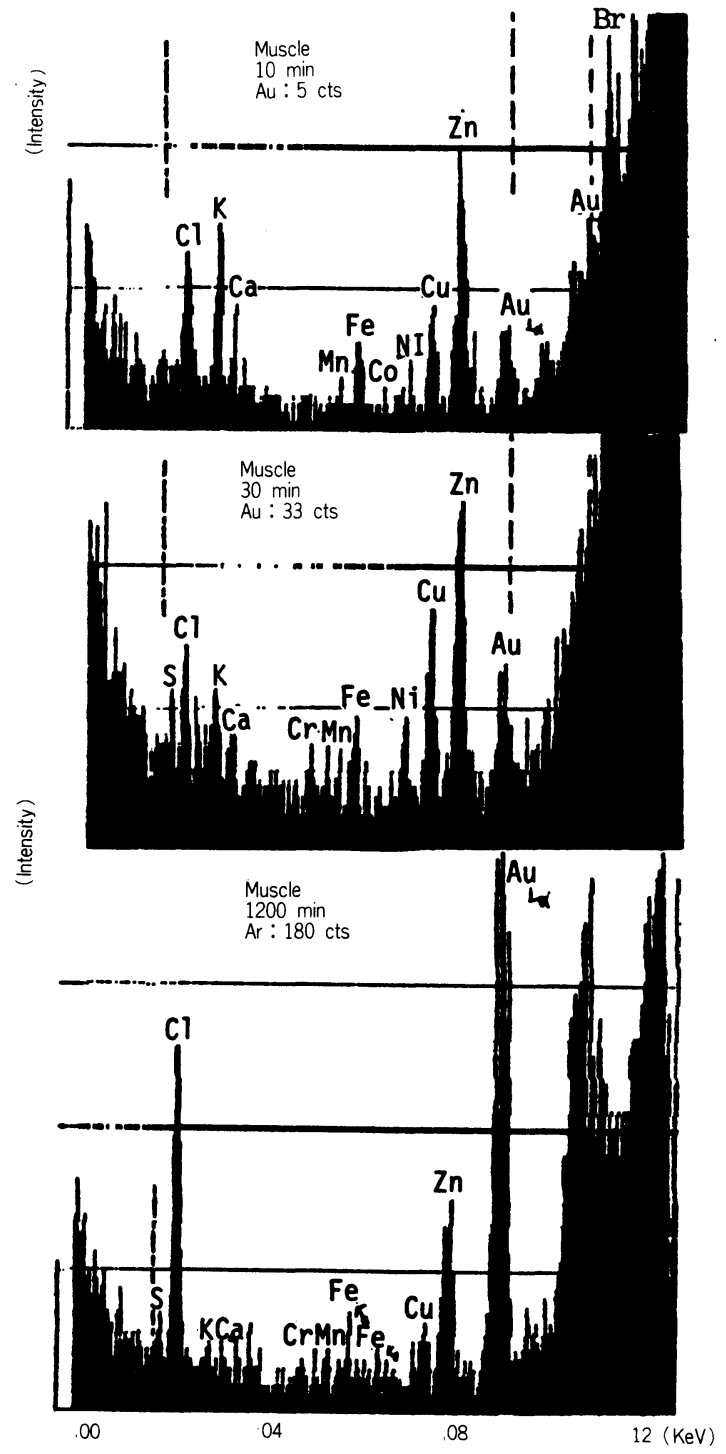

Fig. 5 Displacement of Distribution

ただし，Rは気体定数，Tは絶対温度， $\chi$ は移動 距離, $\phi$ は電位, Zは電気量, Fはファラデ一定数 である。

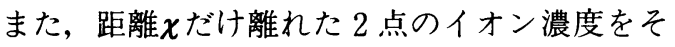
れぞれ $\mathrm{C}_{0}, \mathrm{C}_{x}\left(\mathrm{C}_{x}>\mathrm{C}_{o}\right)$ とすると

$$
\left\{\begin{array}{l}
\mathrm{J} \fallingdotseq-\mathrm{D}\left(\frac{\mathrm{C}_{x}-\mathrm{C}_{o}}{x}\right) \\
\mathrm{J} \fallingdotseq-\mathrm{P}\left(\mathrm{C}_{x}-\mathrm{C}_{o}\right)
\end{array}\right.
$$
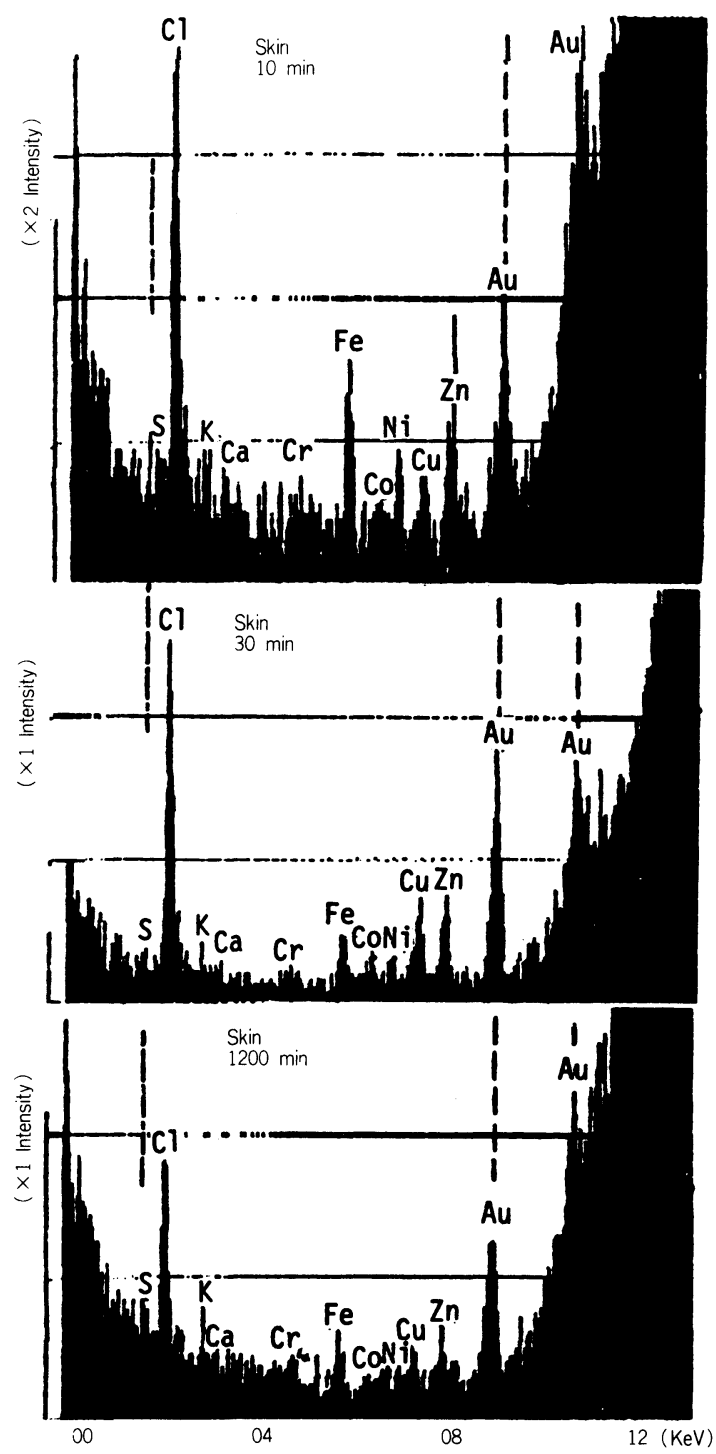

Fig. 6 Displacement of Distribution

となるからこれより

$$
\mathrm{P} \fallingdotseq \frac{\mathrm{D}}{\chi}
$$

が導びかれる。すなわち, Pは距離 $\chi$ に反比例して 小さくなっている。われわれの求めた $\mathrm{D} は \mathrm{D} \fallingdotseq 0$. $46, x \fallingdotseq 2.0 \mathrm{~cm}$ であるから， $\mathrm{P}$ は $\mathrm{P} \fallingdotseq 0.23$ となる。

それで，われわれが求めた拡散分布方程式はど のようなものかを考えるとき，まず拡散係数Dは 組織の集合的定数であることより，生体膜の透過 性に影響するすべての因子に関する值を含まねば 
ならないことになる移動 係数 (transfer coeffient）に相等するものと考 えられるので, この拡散 分布方程式は輸送に関す る次の一般式皇と対をな すものでなければならな いと考えられる。

$$
\frac{\mathrm{dC}}{\mathrm{dt}}=\mathrm{k}_{i} \mathrm{C}_{o}-\mathrm{k}_{o} \mathrm{C}_{i}
$$

ここで，tは時間，Cは濃 度, $\mathrm{k}_{i}, \mathrm{k}_{o}$ は $\sec ^{-1} て ゙$ 表わ される内向きフラックス (influx), 外向きフラッ クス (outflux) に対する 比移動係数, $\mathrm{C}_{o}, \mathrm{C}_{i}$ は膜 の外側と内側におけるイ オンの濃度である。それ ゆえに，この式は，濃度

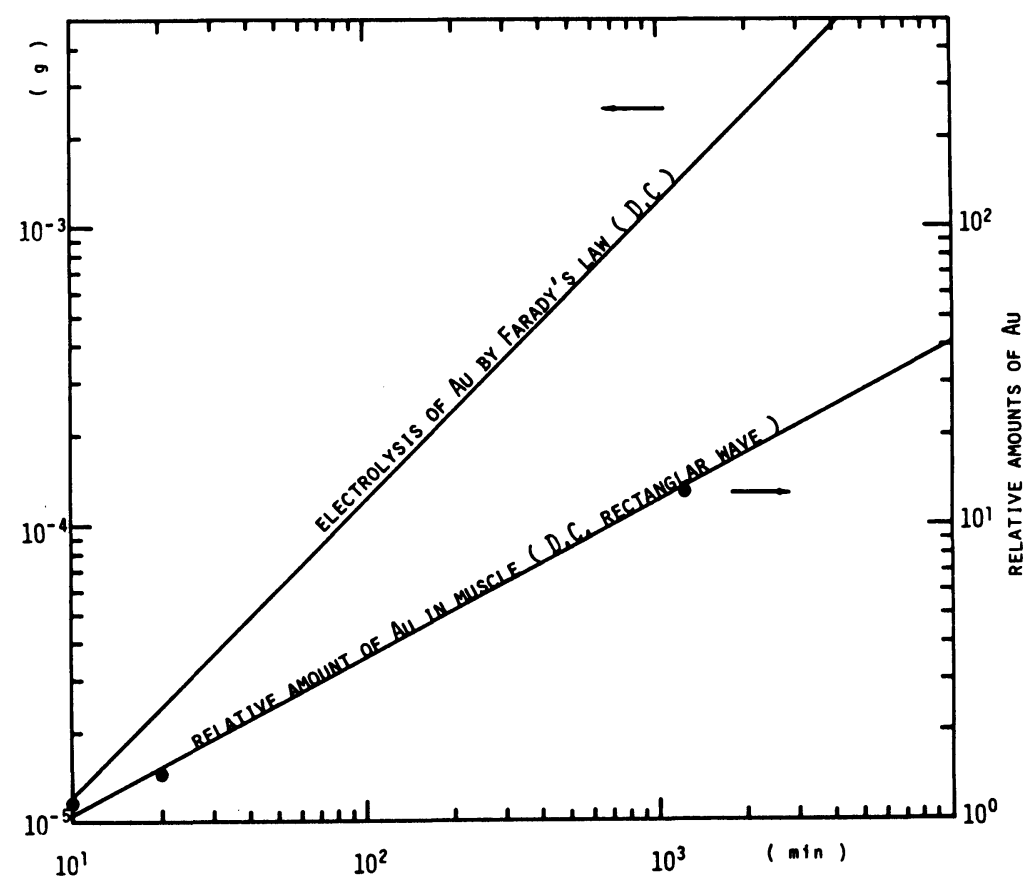

Fig. 9 comparison between theoretical and experimental
変化は入ってくる量から出ていく量の差に等しい ことを意味している。したがってわれわれの求め た拡散分布方程式は当然この現象を記述している ことになる。

〔刺入金属銊による組織内金属イオンの変化に ついて]

Table 1 より得られる顕著な状況は次の 4 点で ある。

第 1 点は, 金 $(\mathrm{Au})$ のイオンのイオン化量は刺 激時間の増大に伴い増加することである。これは 筋肉において顕著である。Fig. 9 が示すように, ファラデーの法則によるAuの電気分解量は時間 に対して正比例関係にあるが，筋肉内におけるイ オン化量は正比例関係にはないことがわかる。こ のことば細胞内の各種金属イオンによって刺入金 属イオンのフラックスが抑止されるためであろう と考えられる。

第 2 点は, Fig. 7 がその状況を示しているよう にKイオンの量は刺激時間の増大に伴い明らかに 減少することである。これは細胞内におけるKイ オンが蛋白質との結合が弱いことが原因となり, 蛋白質と結びつきやすく重い陽イオンのフラック スによって，押し出されてしまうものと考えられ る。
第 3 点は, $\mathrm{Au}$ 銊の通電刺激により, 各種金属イ オンの相対的濃度比が変動することである。これ は異種イオンの混入により，共役なイオン関係を 保つイオンと, 非共役なイオン関係になるイオン とがあることをサジェストしている可能性があ る。

第 4 点はFig. 8 で明らかなように, Au銊刺入部 における,より重い金属の含有量は ( Au鍼刺入部 から遠い部位の含有量よりも), 相対的に多く, 逆 に, Au鍼刺入部における,より軽い金属の含有量 は, (Au鍼刺入部から遠い部位の含有量よりも), 相対的に少ない結果になっている。このことは, 外部からの遷移金属イオンの混入により, 内在し ていたイオンが共役なイオン関係と非共役なイオ ン関係になることを含めながら，内在していた遷 移金属イオンの集合化作用を可能にしているとい う可能性がある。

\section{5. 結論}

遷移金属銊刺入による生体金属イオンの存在様 態を、特性X線により分析することができる。その 結果は次の通りである。

1. 刺入金属イオンの時間経過に対する拡散分 布方程式を決定することができる。 

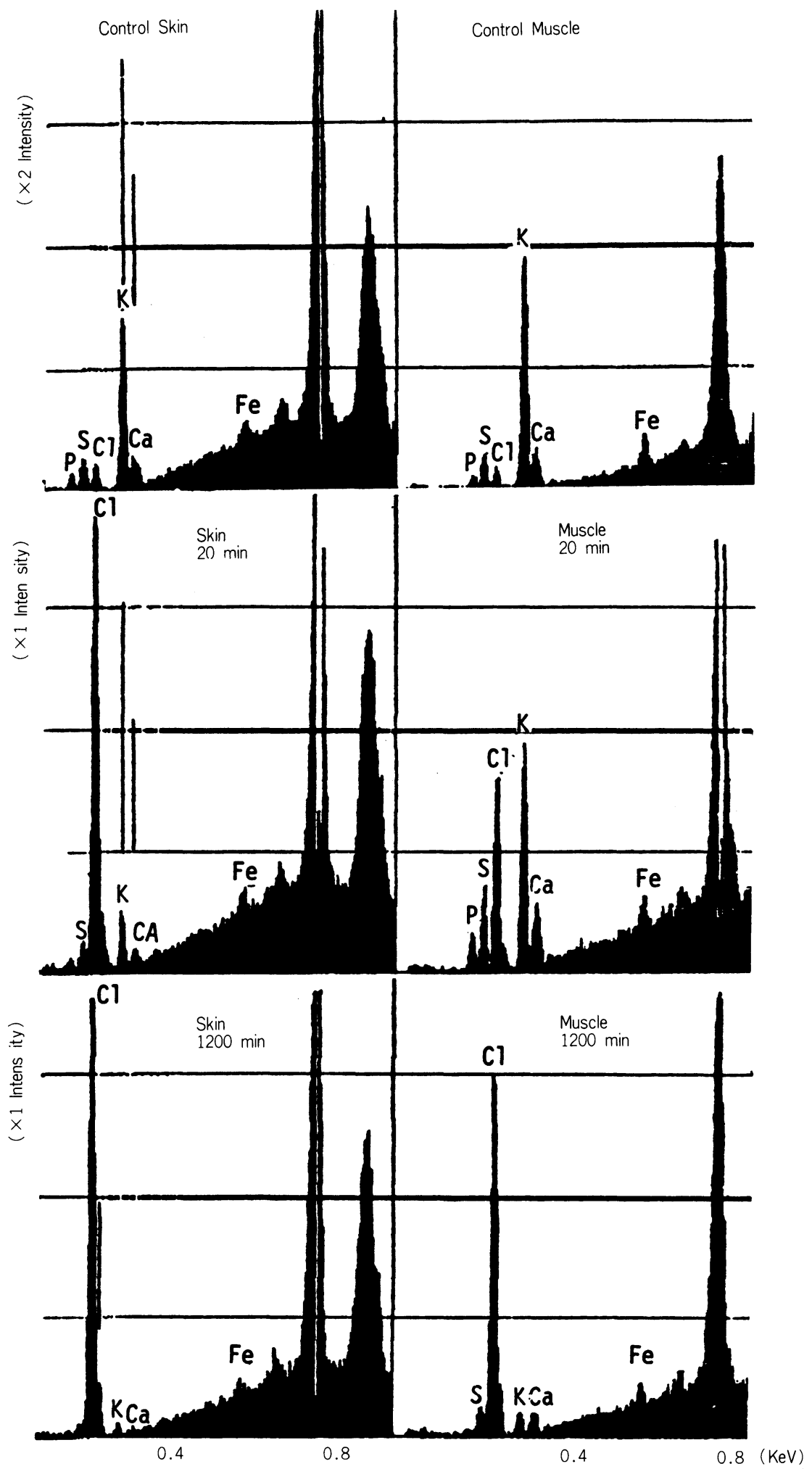

Fig. 7 relative distribution of non-transition elements 


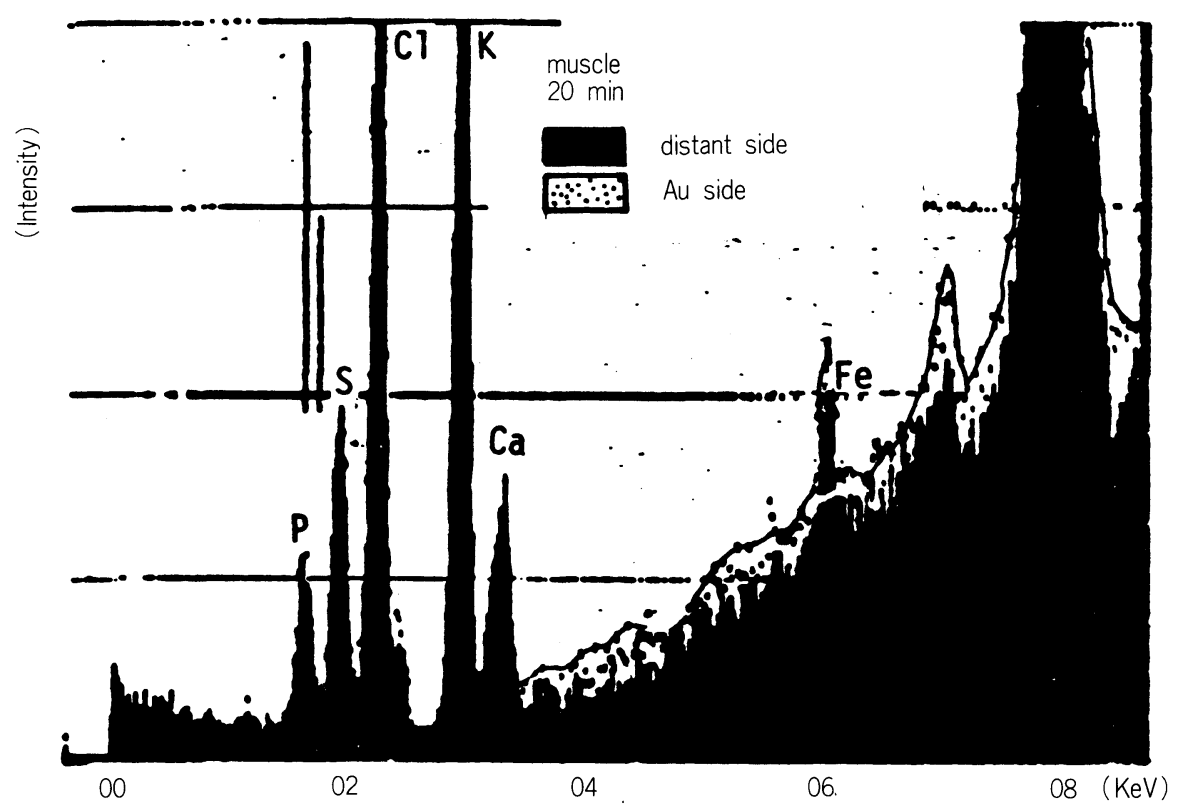

Fig. 8 comparison between Au side and distant side

2. 刺入金属イオンのイオン化量は時間に正比 例する関係には従っていない。つまり,ファラデー の電気分解の法則には従っていない。

3 . 刺激時間の増大に伴いKイオンの量は刺入 局所において減少する。

4. 刺入金属イオンによって, 内在している遷 移金属イオンは共役的に作用している。

5. 微量元素の変動の原因は本実験では解明さ れていない。

おわりに，本実験をするに際し，堀場製作所開発 部の細川好則氏ならびに泉昭太郎氏には装置につ いてのご協力を頂くことができ，謝意を表する次 第である。

\section{引用文献}

1) H.J.M.Bowen : Trace elements in biochemistry, Academic Press, 1966

2 ) A.S.Prasad(ed.): Trace elements in human health and disease, vol.II, Academic Press, 1976

3 ) E.J.Underwood: Trace elements in human and animal nutrition, 4th.ed., Academic Press, 1977

4) 日本化学会編：錯体化学からみた生体系とその モデル, 化学総説NO.20, 学会出版センター, 1978
$5 ）$ 二本柳賢司・成田正次：鍼成分のイオン化に起因 する諸効果について, 自律神経雑誌, $25,3.4$, 112 117, 1979

6 ）二本柳賢司・成田正次：MOと $\mathrm{Fe}$ を含む合金銊の 生化学的効果について, 第 27 回日本銊尒医学会 学術総会誌，63～71，1978

7 ) Hirokazu Kato. Ryoichi Ono and Ryuhei Kato Absorption of high energy electrons in liguid medium, Nuclear Instruments and Methods 145, 525 528, North-Holland Publishing Co., 1977

8) Takao Igaki, Te Hanai, Takehiro Nishidai, Mitsuyuki Abe and Hidekuni Takekoshi: PIXE Analysis using Kyoto University Cyclotron, Bulletin of the Institute for Chemical 算 - 一, 63 67, 化学同人, 1978

9) W.C.Holland,R.L.Klein， A.H.Briggs著大木幸 介, 林勝哉訳：分子薬理学序説, 103 105, 東京 化学同人, 1967

10）花井哲也：膜とイオンー一物質移動の理論と計 算一一, 63 67, 化学同人, 1978

（干 621 京都府亀岡市薭田野町芦/山杉森 6-29） 


\title{
Analysis of Metals in Tissues Through Characteristic X-Rays
}

\author{
Kenji Nihonyanagi \\ Nagoya City University Medical School, the 1st Department of Physiology \\ Ryoichi Ono and Ryuhei Kato \\ Ritsumeikan University, Department of Mathematics and Physics, nuclear physics
}

The +2 ions in the extenal fluids of the cells touching the outer surface of the nerve membranes are indespensible to excitation; if a +1 ion is added, excitation becomes easy. In the inner fluids touching the inner walls of the membrane with the existence of +1 ions only there is no problem, but if $\mathrm{a}+2$ ion happens to come to exist within these inner fluids generally, this results in a decrease in the active electrical potential.

Very little is known about the quantitative tendencies of trace metal elements (or ions) within the local domain of the human tissue however the verification of the amounts of VIa (Cr, Mo), VIIa (Mn), VIII (Fe, Co, Ni, Pt), Ib (Cu, Ag, $\mathrm{Au})$ transition metal elements and $\mathrm{IIb}(\mathrm{Zn}, \mathrm{Cd})$ among the heavy metal elements existing in the human body is a matter of great physiological and pathological importance.

We will report information concerning metals among heavy metals and the transition metals in which characteristic X-rays appeared notably in this experiment.

The results of this experiment indicate the following: (1) We can induce the equation of diffusion and distribution concerning to the ions of metal element introduced into the skin and the muscle. (2) The amount of ionization of metal elements introduced into the tissues is not abided by Farady's law of electrolysis. (3) In proportion as time of stimulation increases the amount of K-ions in the local domain punctured by Au-needle. (4) As the effect of metal element punctured and introduced into the tissues, the ions of the transition metal elements that were already existing in the tissues are acting in conjunction with the introduced element. (5) The cause of variation on the trace element is not analyzed in this experiment. 